\title{
The impacts of fundraising periods and geographic distance on financing music production via crowdfunding in Brazil
}

\author{
Wesley Mendes-Da-Silva $\cdot$ Luciano Rossoni • \\ Bruno S. Conte $\cdot$ Cristiane C. Gattaz • \\ Eduardo R. Francisco
}

Received: 11 September 2014/ Accepted: 10 April 2015/Published online: 1 May 2015

(C) The Author(s) 2015. This article is published with open access at Springerlink.com

\begin{abstract}
We conduct an analysis of 1835 pledges to 10 music production projects hosted on the largest Brazilian crowdfunding platform, namely the Catarse Web site, and we assess the relation between the fundraising accumulation period, the donor-entrepreneur distance and the propensity of donors to back projects. Our results suggest a significantly negative association between distance and the value of capital pledged to projects, which is consistent with the notion that the entrepreneur's network of close contacts might play a central role in funding. Furthermore, our results contradict the idea that crowdfunding reduces the inhibiting effect of donor-entrepreneur distance. In addition, the results show that a long project exposure is associated with higher values of pledges. These results suggest practical implications for the study of crowdfunding as a financing platform. This
\end{abstract}

\footnotetext{
W. Mendes-Da-Silva · B. S. Conte · E. R. Francisco

Fundação Getulio Vargas Business School at São Paulo, Rua Itapeva, 474, 8th Floor, São Paulo, SP 01332-000, Brazil

e-mail: mr.mendesdasilva@gmail.com

B. S. Conte

e-mail: brunoconte1@gmail.com

E. R. Francisco

e-mail: erfrancisco@gmail.com

W. Mendes-Da-Silva

Brigham Yung University, Provo, UT, USA

L. Rossoni ( $\bowtie)$

UniGranRio and Brazilian Institute of Social Research (IBEPES), Rua da Lapa, 86, Centro,

Rio de Janeiro, RJ 20021-180, Brazil

e-mail: 1rossoni@gmail.com

C. C. Gattaz

Centro Universitário da FEI, Rua Tamandaré, 688, Liberdade, São Paulo, SP 01525-000, Brazil e-mail: cristiane.gattaz@gmail.com
} 
study contributes to the literature on the use of crowdfunding as an alternative funding source in a major emerging market.

Keywords Brazilian music - Crowdfunding - Financial innovation - Geographic dispersion $\cdot$ Fundraising period $\cdot$ Social networks

JEL Classification $\mathrm{G} 32 \cdot \mathrm{L} 11 \cdot \mathrm{L} 13 \cdot \mathrm{L} 15 \cdot \mathrm{L} 21$

\section{Introduction}

Brazil is one of the major music producing and consuming regions worldwide, and it had the 11th largest market in 2009 (IFPI 2010). Although $58 \%$ of the market was national and $90 \%$ of the best-selling albums were by local musicians in 2009 (IFPI 2014), music production differs little from the world market, as a few record companies compose the local market (Cassiolato et al. 2008). As such, the cost of entry for budding musicians is high (Cameron 2015). Although there is often demand from Brazilian artists for financing their activities (Lucas 2000), access to resources for beginners is scarce. Indeed, if we consider musicians as entrepreneurs, at the outset of their initiatives they find it difficult to attract external capital. The problem of accessing specific financing sources is inherent to their initial stage (Berger and Udell 1998; Cosh et al. 2009). This difficulty places a limiting factor on the entrepreneur's chances of survival and growth, especially given the lack of true guarantees and what potential investors would view as sufficient cash flows or good reputation. It should also be noted that investors are faced with asymmetric information. According to Cosh et al. (2009), entrepreneurs requiring smaller amounts of capital are unable to access venture capital, private equity or banks, which may be available in other stages. Hence, these entrepreneurs tend to find backing from: (1) their own resources, (2) their family and (3) their circle of close friends (Parker 2009; Sheng and Mendes-da-Silva 2014).

Crowdfunding has become an innovative method for bringing investors and those requiring capital closer together, especially when the latter are developing artistic, cultural, social or other types of initiatives (Shiller 2013). This method has enabled relatively small sums pledged by a large number of people to make businesses viable in a more flexible and less costly way that does not require intermediate financiers. A large number of platforms for raising funds through crowdfunding have appeared as a result of this phenomenon. One example is Kickstarter (https:// www.kickstarter.com/), which is currently the largest platform in the world. Kickstarter is a North American website hosting projects including films, games, music, design and technology. Since its launch in 2009, it has attracted more than R \$ 1.5 billion from 5.1 million people to finance more than 50,000 creative projects (Qiu 2013).

Although the World Bank (2013) and specialized consultants point to the rapid growth of this financing mode, it still tends to be highly concentrated in North America and Europe (59 and $35 \%$ of the total value around the world, respectively) with a negligible presence in developing continents. South America, for example, 
represented only $0.03 \%$ of this market and that portion exceeded only the corresponding one for the African continent, which represented just $0.003 \%$ (Massolution 2013). In addition to the social impact of crowdfunding and its interest from the financial media, and more recently, the academic business community (Shiller 2013; Mollick 2014; Bruton et al. 2015), various governments have recognized its relevance to developing countries (Royal and Windsor 2014), and consequently, they have given attention to regulating this activity (Agrawal et al. 2014). For example, the US Government recently approved legislation entitled the Jumpstart Our Business Startups Act (JOBS Act), which has the main objective of stimulating access by companies in the emerging growth stage (Stemler 2013).

In finance, investors tend to demand relatively more information from embryonic businesses, given the high level of risk when dealing with new businesses (Berger and Udell 1998). Investors in startups also tend to prefer businesses that are physically closer, as they are motivated by the wish to reduce the information asymmetry (Lee et al. 2008). However, crowdfunding allows an unlimited number of geographically dispersed people to be reached for the purpose of obtaining small amounts of money for financing a project or enterprise. It also allows business activities to be monitored as they progress, and this monitoring can occur over large distances, which will reduce information asymmetries. Moreover, in their mode of pledges, creative entrepreneurs like musicians can overcome problems of market capitalism as a delivery mechanism (Cameron 2015).

This article examines the associations that exist between the fundraising period, geographic distances, socioeconomic factors and the pledges made to projects financed through crowdfunding in an emerging economy. For this purpose, the data that were analyzed are related to 1835 pledges toward ten music production projects that were judged to be successful on the main Brazilian crowdfunding platform in 2013: Catarse. This work is organized in five sections. Section 2 presents background material about crowdfunding, its uses and the hypotheses tested in this study. Then, Sect. 3 sets out the methodology we used. The results are discussed in Sect. 4, and our conclusions are given in Sect. 5.

\section{Background}

The so-called subprime crisis was the worst financial crisis since the Great Depression according to Shiller (2013). This crisis has been perceived as due to failings intrinsic to the financial system and the people running it. In particular, financial agents have been seen as one of the principal causes of the crisis for working excessively for their own benefit. According to Shiller (2013), the financial industry needs time to rebuild its reputation with society, and this process is characterized by the emergence of financial innovations, e.g., social impact bonds and crowdfunding. In this sense, crowdfunding is frequently identified as one of the most relevant modern financial innovations (Kuti and Madarász 2014). This financing method has emerged as a novel way of raising capital for entrepreneurial ventures (Macht 2014), and it frequently occurs through the internet. Crowdfunding has enabled different business types, such as agribusiness, social projects, 
technological innovation projects and particularly cultural production, without the pitfalls of traditional methods of financing (Braet et al. 2013; Lehner 2013; Schwartz 2013; Agrawal et al. 2014). We focus on this novel funding method in the case of music.

\subsection{Definition and uses of crowdfunding}

Crowdfunding has been seen as a tool that enables the democratization of financing (Brabham 2008; Kim and Hann 2014) and as an innovative method of financing. It is normally enabled through the internet by means of social media (Lehner 2013), and it allows entrepreneurs to reach geographically dispersed people around the globe who are willing to support the project (Saxton and Wang 2014). Crowdfunding has been described as the accumulation of small investments in individual projects by a large number of individuals who are supported by a platform (Royal and Windsor 2014). One of the characteristics of crowdfunding projects is the existence of a funding target. Often a campaign exceeds $100 \%$ of its funding target, which is known as "overfunding," entrepreneurs are not required to take investment but reserve the right to accept any amount beyond $100 \%$. In the particular case of this research, the excess funds are delivered to the entrepreneur's musical project. According to Royal and Windsor (2014), the platform allows project initiators to upload projects to the platform online for others worldwide with similar interests to contribute financially.

According to Mollick (2014), the most basic variations in crowdfunding relate to the objectives pursued by the entrepreneurs and investors, called "donors" hereafter. As in the specific case of this article, the people who are interested in music production projects are not necessarily interested in financial returns, as discussed by Kuti and Madarász (2014) and Royal and Windsor (2014). By means of these platforms, the entrepreneur can seek a small sum, e.g., a few thousand Brazilian reals or less, to fund a specific project that is motivated by their own dream or objective. Usually, these types of projects receive the majority of their funding from the entrepreneur's social network, i.e., his or her network of personal contacts (family and friends) (Agrawal et al. 2011; Sheng and Mendes-da-Silva 2014). These social networks provide additional support that such funding does not customarily receive from angel investors, such as advice, governance and prestige (Ferrary and Granovetter 2009). From this starting point, recent studies have highlighted these aspects as pertinent to a relevant research agenda on the theme of crowdfunding (Lehner 2013).

As crowdfunding has evolved, it has reached a growing segment of the public and is no longer restricted to being an alternative way for entrepreneurs or startups to attract funding for their projects. It has evolved so that crowdfunders can perform support roles. By way of illustration, in certain circumstances crowdfunding may be used to achieve the simple objective of raising awareness about a new project as part of a marketing campaign that directly involves consumers (Cameron 2015). The interested company is able to gauge whether there is demand and how much demand there is for a specific product (Schwienbacher and Larralde 2012). 
Although crowdfunding can be used with the intention of participating in the equity of the company, this research focused on projects without this characteristic. Among these projects, Agrawal et al. (2014) highlighted seven characteristics in their review: (1) the funding is not geographically concentrated; (2) the values of pledges are highly asymmetric; (3) the propensity to invest increases as capital accumulates during the fundraising period of the project, with the risk that investors will follow herd behavior; (4) friends and family play a key role in the initial stages of the fundraising process; (5) the funding follows concentrations that already existed; (6) entrepreneurs and investors tend to be highly optimistic at the outset about the results of the project seeking investment; (7) lastly, the capital attracted by means of crowdfunding might replace traditional financing sources.

In addition to these peculiarities, just as the objectives pursued by entrepreneurs vary, the motivations of the investors may also vary according to the nature of the project (Belleflamme et al. 2014). There are essentially four models for how individuals provide their sponsorship to projects (Kuti and Madarász 2014; Royal and Windsor 2014). The first model is donation-our case in this research, which applies mainly to projects that are characterized as artistic, humanitarian and socioenvironmental. The sponsorship is in many cases virtually philanthropic. In other words, the investor does not expect a direct personal return from the donation. The second model is based on credit: The funds are provided to the entrepreneur as a loan with an expected return rate. This model does not (currently) exist in Brazil, as this activity is restricted to financial institutions by law. The third and most widespread crowdfunding model to date is based on nonfinancial compensation: Investors receive something in exchange for sponsoring the project. Individuals usually receive the product that was the objective of the appeal, such as books, CDs, DVDs, show tickets or a wide variety of other things. Finally, there is equity crowdfunding, in which the sponsors are effectively investors and receive a share in the equity of the company they finance. This practice is still rarely found in active use worldwide due to regulatory obstacles (Heminway and Hoffman 2011; Ahlers et al. 2012), and it represented just $5 \%$ of the total volume of funds managed through crowdfunding platforms globally in 2013, according to Massolution (2013).

\subsection{Literature review and hypotheses}

Due to the possibilities offered by the internet, geographic dispersion is probably one of the most common characteristics of crowdfunding operations. Lee et al. (2008) suggest that the arrival of Web 2.0 simplified the sharing of information within the environment of large social networks at reduced costs. This simplification has contributed to establishing governance mechanisms for the enterprise. Put another way, the arrival of online crowdfunding platforms provided a tool to bring the investor and entrepreneur closer together and to share information with greater transparency for project budgets and the necessary details on the destination of the raised funds. Additionally, it became possible: (1) to monitor the whole process (with entrepreneurs having access at any time to all of the investors in the project), (2) to see the percentage of the fundraising target already achieved and (3) to see the remaining time the fundraising period had to run. 
From this point of view, based on data covering the period from August 2006 until September 2009, Agrawal et al. (2011) analyzed 34 projects that received 24,862 donations (representing $73 \%$ of the total amount invested in the website) in the Dutch platform Sellaband (https://www.sellaband.com), which is a site for musicians wanting to raise funds to launch their albums, to investigate whether crowdfunding is sensitive to the investor-entrepreneur geographic distance. The average investor-entrepreneur distance found by Agrawal et al. (2011) was approximately $4,828 \mathrm{~km}$, which is greater than the distance between the most southern and northern parts of Brazil (about $4300 \mathrm{~km}$ ). In their study, the data indicate that the greater the investor's proximity to the entrepreneur is, the greater the value of the donations will be. According to Agrawal et al. (2011), although crowdfunding suggests a reduced role for spatial proximity, it does play a role.

Regarding the works on crowdfunding, it should be noted that often works found in the literature do not discuss with proper depth, statistical significance in relation to the magnitude of the economic impact of the variables, as discussed by Drummond and O'Brienm (1993) and Miller and Rodgers (2008). In this regard, Agrawal et al. (2011), using models of binary response, indicate that investment propensity increases with funds raised. And relative to an entrepreneur with $<\$ 10,000$ investment, an investor is 2.1 percentage points more likely to invest in a given week if the entrepreneur has $\$ 10,000-\$ 20,000$ and 8.4 points more likely to invest if they have more than $\$ 40,000$.

The authors argue that this geographical effect is driven by investors who likely have a personal connection with the artist-entrepreneur, e.g., family and friends, although they do not present empirical evidence about these social relations. They conclude that the online platform seems to eliminate most distance-related economic frictions, such as monitoring progress, providing input and gathering information; however, it does not eliminate social frictions. In the same line of thinking, a set of studies, e.g., Sorenson and Stuart (2001), Zook (2002), Mason (2007) and Martins (2015), assumes that investors in enterprises in their initial stages tend to demand more information, monitor the business's progress and also participate in decisions about how the business is run.

These activities result in costs that are sensitive to the investor-entrepreneur distance. Based on a sample of American Venture Capitalism Firms, Sorenson and Stuart (2001) found that the probability of investing in a new venture falls with increasing geographical distance. Zook (2002) also found similar results to these authors' analysis for the American internet industry between 1994 and 2000. According to these authors, although communication technologies and the global financial market have geographically expanded the scope of economic interactions, they tend to occur regionally. Martins (2015) points out that when there are cases of investment outside the domestic sphere, for example, investment in projects in the BRIC countries (Brazil, Russia, India and China), the risks and costs tend to be mitigated through arrangements established between venture capitalists.

The results of these studies show that the greater the distance between investors and the project is, the less likely the investors are to invest, and furthermore, they will probably invest less. However, in the musical production context, we must examine the mechanisms underlying the proximity of the donor and the amount 
donated. Crowdfunding in the music industry cannot be seen only as an intermediary agent, as it is also the locus where social connections between fans and musicians occur (Zheng et al. 2014; Colombo et al. 2015). These fans do not just invest in the project of a singer or a band: They are meeting the request of people who are part of their social network (Saxton and Wang 2014) or are feeling motivated to act prosocially (Ariely et al. 2009). For these reasons, we advocate that the mechanisms inherent in the social capital of musicians and the behavioral aspects of donors simultaneously affect the relationship between the geographic distance and the value of a pledge.

According to Nahapiet and Ghoshal (1998, 243), social capital can be defined as "the sum of the current and potential resources embedded within, available through, and derived from the social contacts of an individual or an organization." In the crowdfunding context, these personal contacts, such as friends, intense fans and family, often tend to be closer to the authors of the projects (see McPhearson et al. 2001). Moreover, because the contacts are parts of the authors' real social networks, it is likely that these contacts are direct targets of funding campaigns. Indeed, using data from Sellaband, Agrawal et al. (2011) found that not only did most of the donations occur in the same geographical area or in nearby areas, but these donations also had the highest value. Although they have not considered the distance of ties between donors and musicians, Mollick (2014) and Zheng et al. (2014) identified a positive relationship between the number of social contacts identified on Facebook or other social networks (e.g., Weibo Page, a Chinese social network) with the amount donated and with the musical project's performance. These results are also supported by Saxton and Wang (2014), who found that nonprofit organizations with more Facebook fans receive more donations, and by Colombo et al. (2015), who found that greater numbers of contacts on Linkedin were associated with both the number of supporters and the volume of capital raised in 669 projects on the Kickstarter platform.

In addition to this evidence that more frequent and more valuable donations come from people with personal ties who are geographically closer, it should be noted that relations' networks are also mechanisms of coercion (Coleman 1990; Matzat 2004) in which socially closer donors to the entrepreneur who are more densely grouped tend to feel more motivated or morally obliged to donate larger amounts. The donors can include even the most avid fans appealing for recognition by the musicians. ${ }^{1}$ This behavior in the act of giving to musical projects in crowdfunding happens not only for personal reasons or for direct benefits (for example, received gifts), but also because donors want to obtain a good image or desire the respect and approval of the connected community that is raising money (Ariely et al. 2009). These networks of relations (as we have said) tend to be geographically close to the entrepreneurs. From these arguments, it is relevant to test hypothesis $\mathrm{H}_{1}$ :

$\mathrm{H}_{1}$ There is a negative association between the geographic distance separating the entrepreneur and the donor and the value of the music crowdfunding investments.

\footnotetext{
1 The authors thank Editor Samuel Cameron for having pointed the role of fans.
} 
In addition to evidence of the relationship between the proximity and pledge value, Agrawal et al. (2011), Zhang and Liu (2012) and Kuppuswamy and Bayus (2014) assumed that the volume of accumulated pledges grows as the fundraising time increases. Accordingly, these authors suggest that the propensity for a potential donor/investor to sponsor a project increases, which might suggest some type of herd behavior by investors. Burtch et al. (2013) identified crowd's herding behavior as a possible influencing factor for participation in crowdfunding.

The herding behavior acts as an uncertainty reduction mechanism and may result in greater density in the project supporters' network. The reason is that with an increase in the number of donors, it is more likely that these donors will have links between themselves, which would make them more visible to each other (see Burt 2005). Indeed, the increased redundancy enables the network to operate as a coercive apparatus (Matzat 2004), as those who have not yet supported an endeavor feel increasingly obliged to contribute (Ariely et al. 2009). In addition, this sense of obligation, which grows with the project exposure, should affect not only the likelihood of contributing, but also the value of the donation. As Ariely et al. (2009) discussed, in the desire to be socially approved, donors feel morally obligated to contribute a proportional or greater value. It should be considered that this behavior is reinforced in social networks, as one of its key features is the reciprocity in trade (Mendes-da-Silva et al. 2008; Zheng et al. 2014).

Still, there is another element to consider: the relationship between the exposure time (time from the announcement of project) and a donation's value. As indicated by Colombo et al. (2015), social capital is important to raising money. Thus, we investigate whether the origin of the actors that promote this social capital matters. At this point, we divide the social capital into two types: (1) external social capital, which is derived from social relations outside of the crowdfunding community, such as friends, family or intense fans; (2) internal social capital, involving those relationships that are established within the crowdfunding community, usually composed by donors and fans and enthusiasts with weaker relationships with entrepreneurs. Colombo et al. (2015) showed that the internal social capital significantly affects the number and value of donations in the early stages. These actors belong primarily to the internal network community, and they tend to have faster access to new campaigns in crowdfunding platforms, which increases the chance of them donating in a project's early stages. In the case of external social capital, which is designed by the friends, family and intense fans of the proponents, these contacts are commonly not connected to crowdfunding platforms. Thus, it is expected that the investors who are not socially connected to the entrepreneurs tend to take longer amounts to donate than others. Nevertheless, donors with close ties to the musicians tend to donate larger amounts (Saxton and Wang 2014). Given the above reasons, we believe that the greater the exposure time of the project is, the greater the value of the donations will be. This line of thinking leads to testing hypothesis $\mathrm{H}_{2}$ :

$\mathrm{H}_{2}$ There is a positive association between the fundraising accumulation period via crowdfunding and the value of the new pledges received by the music entrepreneur. 


\section{Methodology}

In this section, we describe the data collection procedures, we present the platform used in the study and we present the empirical strategy that we adopted.

\subsection{Data collection}

In November 2013, when the data analyzed in this study were collected, Brazil had 40 crowdfunding platforms that were listed on specialized sites, e.g., (http:// mapadocrowdfunding.tumblr.com). Among the different types of projects sponsored, the majority were creative and predominantly cultural projects, although there were other more specific objectives, e.g., financial support for soccer clubs at (http://vascodividazero.com.br). The dominant site among the 40 crowdfunding platforms is Catarse, which was the focus of this study. Only the Catarse website was considered, and all of the projects meeting the following criteria were selected: (1) The entrepreneurs were musicians who were using the platform to seek funds for financing the first album of their artistic career, and (2) the target funding was between $\mathrm{R} \$ 10,000$ and $\mathrm{R} \$ 30,000$ (US\$ $1,00=\mathrm{R} \$ 2,80$ ); indeed, $95 \%$ of the projects hosted on the platform fall in this range value. Because of that, this range was considered.

The data collection required for constructing the variables under consideration took place in two main phases. The first phase focused on the Catarse platform (http://catarse.me), where two types of data were obtained: data from browsing the website directly and data provided by the platform's founders to its entrepreneurs and sponsors through the privacy policy for the platform. The second data collection phase examined socioeconomic data for the municipalities where the 1835 pledges considered in the research originated. These data were obtained from the Brazilian Institute for Geography and Statistics (IBGE_Instituto Brasileiro de Geografia e Estatística), and we drew on the most recent Brazilian Census, which was conducted in 2010.

The geographic distance between the entrepreneurs and the donors was obtained for the cities where they were located, and we used Google Maps APIs (http://code.google.com/apis/maps/) to identify the coordinates of each location. The distance was calculated using the procedure adopted by Nichols (2003) with the tool ArcGIS ArcMap 10.0 (ESRI 2010). The motivation for using these types of tools comes from the argument that when the data's spatial distribution is related to the phenomena occurring in the territory, one has a modern way to clarify questions related to various fields of knowledge (Ebner et al. 2009). The use of these techniques in the business field is in an embryonic stage (Goodchild 2010), especially in studies of collaborative phenomena (Sui et al. 2013). In addition, geographical information systems (GISs) could be a tool toward providing a spatial explanation of governance, population and cultural assets (Redaelli 2012). 


\subsection{The website studied: Catarse}

The Catarse website (http://catarse.me) was launched in January 2011, and it was one of the first crowdfunding platforms in Brazil. It is currently the largest collective financial community in the country and has already raised more than $\mathrm{R} \$ 12$ million to finance around 800 projects. The way it works is relatively simple and common to most competing sites: The entrepreneur uses the platform as a means to present their idea to the public, specifying the total investment required and the cutoff date for evaluating whether or not it has been achieved. To be able to use this platform for fundraising, the entrepreneur must meet the requirements given in Table 1.

Figure 1 shows a typical project page on the platform we studied. On the right, observe: (1) the number of sponsors already attracted to the project, (2) the total pledged so far, (3) the total requested, (4) the remaining fundraising period, (5) the project description and (6) rewards and other relevant information. Table 2 shows a summary of the profiles of the ten projects selected for this study. Notice that these projects raised nearly $\mathrm{R} \$ 200,522.00$ from 1835 pledges that originated from 151 different municipalities. The second column of the table shows the project that received the greatest number of investment pledges (377 pledges) achieved its target (through the Catarse platform) of $\mathrm{R} \$ 29,400$. Project No. 1 originated from the city of Curitiba in Paraná State, Southern Brazil. We do not highlight the pledge rewards because they were extremely similar and had the same pattern. These projects started with online distribution albums after physical distribution and evolved to give autographs and invitations to release shows.

Table 1 List of requirements for projects hosted on the Catarse website

\# Requirement

1 The project must be complete and have a clear objective or it will not be accepted on the platform

2 The project must present a realistic fundraising target and account for all of the costs and rates involved in a campaign on the platform; all projects must specify a budget that justifies the fundraising target given

3 Together with the target, projects must have a defined fundraising duration (with a maximum of 60 days $^{\mathrm{a}}$ )

4 The fundraising system is "all or nothing": if the given target is not achieved within the specified timescale, the sponsors receive a credit to back other projects, or if they prefer, a refund of their money; additionally, the project receives nothing

5 All projects must offer rewards as consideration to donors for their sponsorship. For example: copies of the work, CDs of music, innovative experiences, limited editions and exclusive benefits. Any form of financial return is prohibited

6 All projects must provide certain information that indicates what it is, what will be done and how the money will be spent

7 A high-quality video explaining the project must be produced

\footnotetext{
${ }^{a}$ Until September 30, 2013, the Catarse platform offered creators of projects that did not achieve their funding the possibility of having a "Second Chance" on the platform if they met certain requirements, with a new fundraising period opening once the project had been redesigned to correct any problems with it. This practice resulted in fundraising periods longer than the 60-day limit. This opportunity was abolished on October 01, 2013
} 


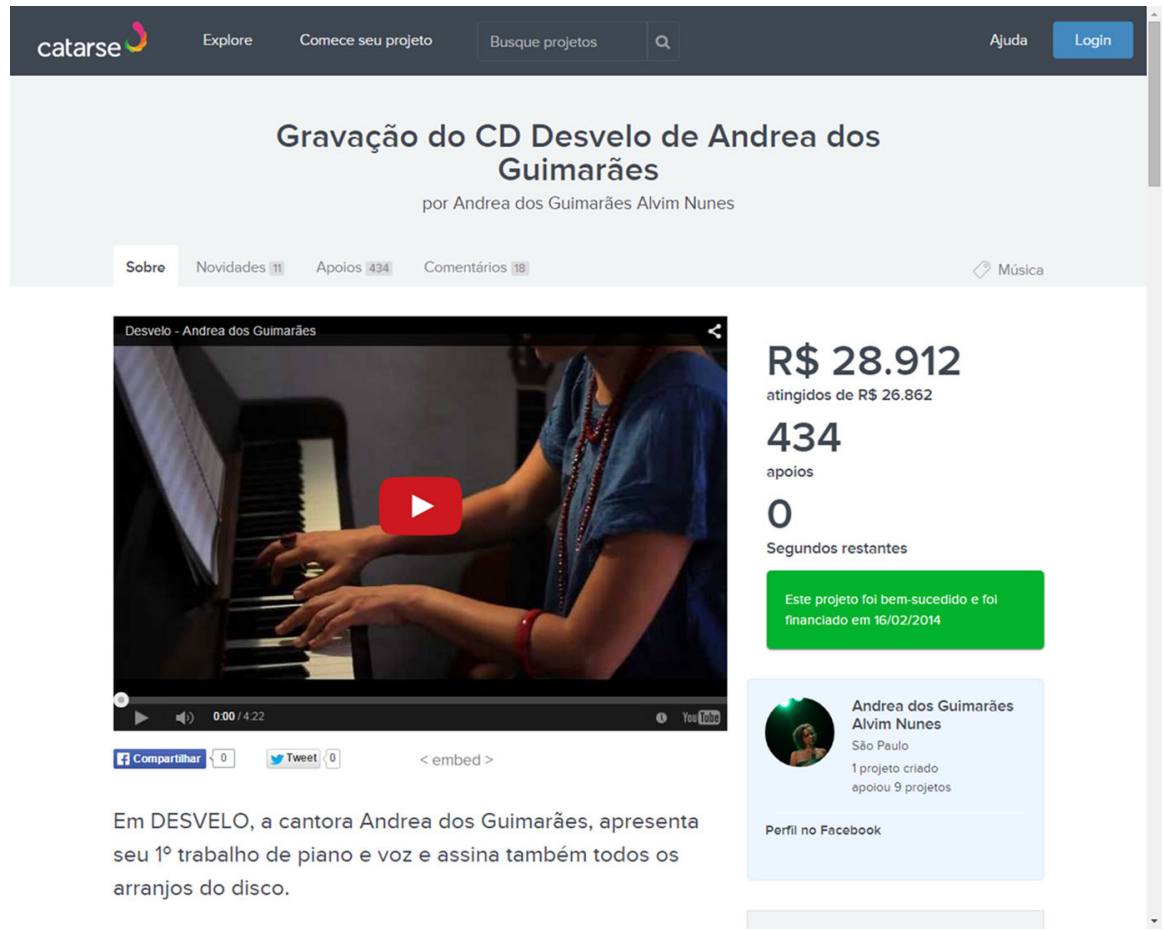

Fig. 1 Schematic view of the Catarse website. Source: adapted by the authors from the Catarse website (http://catarse.me/pt/andreadosguimaraes)

Note that Project No. 1 reached this total after 37 days of fundraising. Figure 2 shows the geographic distribution of the 377 pledges made to Project No. 1 via the Catarse platform, as given in Table 2.

\subsection{Model estimation}

The variables investigated in this study are described in Table 3 and were selected by considering the literature on utilizing crowdfunding as a means to fund music production (Agrawal et al. 2011). The empirical model we tested is represented in (1). The four control variables were designed to assess the persistence of the coefficients estimated for the variables of interest, which are intended to test $\mathrm{H}_{1}$ and $\mathrm{H}_{2}$.

The control variables were selected by considering both the availability of the data provided by the Catarse website and the arguments in the literature, which indicate that it is possible for the dependent variable to be influenced by the control variables (Mason 2007; Agrawal et al. 2011, 2014). Thus, if the control variables have significant correlations with some of the other variables but are not considered 
Table 2 Profile of pledges made to the projects included in the research

\begin{tabular}{lllll}
\hline Project $^{\mathrm{a}}$ & Total raised (in R\$) $^{\mathrm{b}}$ & $\begin{array}{l}\text { No. of pledges } \\
\text { made to the project }\end{array}$ & $\begin{array}{l}\text { City of the project } \\
\text { headquarters }^{\mathrm{d}}\end{array}$ & $\begin{array}{l}\text { No. of } \\
\text { fundraising days }\end{array}$ \\
\hline Project No. 1 & 29,400 & 377 & Curitiba & 37 \\
Project No. 2 & 26,060 & 112 & São Paulo & 60 \\
Project No. 3 & 24,185 & 189 & Niterói & 60 \\
Project No. 4 & 21,180 & 80 & Itapema & 56 \\
Project No. 5 & 20,710 & 266 & São Paulo & 51 \\
Project No. 6 & 20,280 & 129 & São Paulo & 60 \\
Project No. 7 & 15,615 & 190 & Rio de Janeiro & $101^{\mathrm{f}}$ \\
Project No. 8 & 15,452 & 113 & São Paulo & 39 \\
Project No. 9 & 15,070 & 278 & Florianópolis & 60 \\
Project No. 10 & 12,570 & 101 & Curitiba & 35 \\
\hline
\end{tabular}

This table provides information on the profile of each project included in this research. Observe that the project that attracted the largest number of donors raised a total of $\mathrm{R} \$ 29,400$

Source: Developed by the authors from the data provided by the crowdfunding platform Catarse (http:// catarse.em)

a Name omitted for confidentiality reasons

b Total sum in $\mathrm{R} \$$ raised by the project over the fundraising period

c Number of pledges received by the project during the fundraising period

${ }^{\mathrm{d}}$ City in which the candidate project for funds is based

e Number of days that the project was visible on the platform to receive pledges (i.e., investments and donations)

f One of the projects was resubmitted as a "Second Chance," and it reached the funding target 101 days after the start of fundraising

in the model, the relationship between the variables of interest would not be adequately demonstrated. The errors $\varepsilon_{i}$ are assumed uncorrelated, and $E(\varepsilon \mid X)=0$.

$$
\text { Value }_{i}=\beta_{0}+\beta_{1} \mathrm{Da}_{i}+\beta_{2} \text { Dist }_{i}+\beta_{3} \text { GdpCap }_{i}+\beta_{4} \text { Literacy }_{i}+\beta_{5} \mathrm{HDI}_{i}+\beta_{6} \mathrm{Area}_{i}+\varepsilon_{i}
$$

To test the hypothesis, we used linear regression models based on the ordinary least-squares method (OLS model). To check the robustness, first we checked whether the dependent variable had an approximately normal distribution. Because the symmetry and kurtosis were relatively high, we also tested the models with standard errors of the patch through the bootstrapping procedure (Preacher and Hayes 2008) and ran the model with the natural logarithm of the variable. In both cases, the results were consistent with the original template. Second, we evaluated the most appropriate functional form for the regression variables. In all of the cases, the linear function was adequate in other ways that did not significantly increase the fit.

Third, we evaluated whether the errors held heteroscedasticity problems through the White test. Fourth, we assessed whether the models had multicollinearity problems by assessing the tolerances, which were not $<0.2$, and for the variance inflation factor (VIF), which did not show values $>5$. Fifth, we evaluated whether 


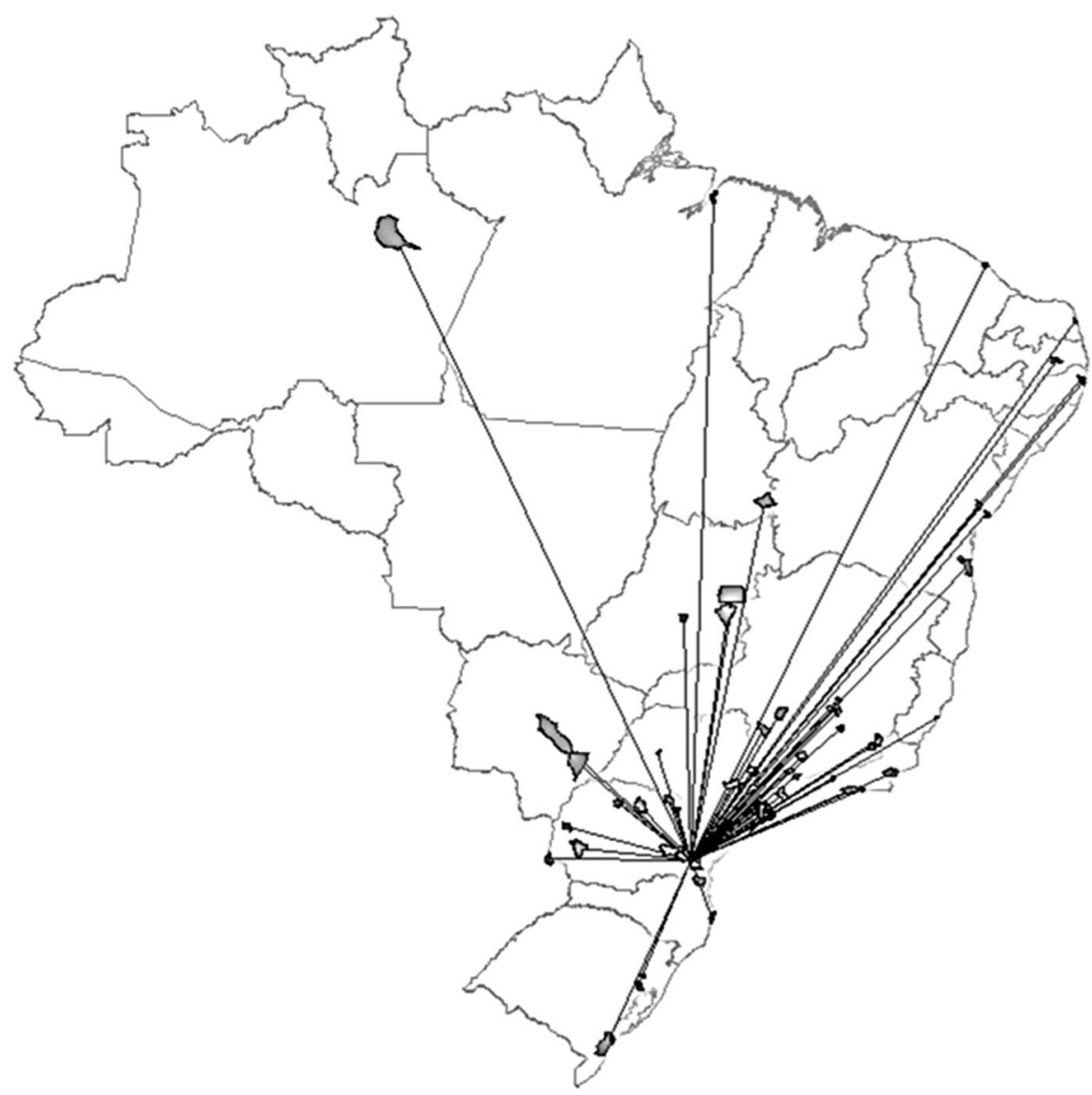

Fig. 2 Presentation of the geographic distribution of the pledges received by Project No. 1. Source: produced by the authors from data obtained from the Catarse platform using the tool ArcGIS ArcMap 10.0 (ESRI 2010). This figure shows the geographic distribution of donors pledging capital to Project No. 1, which attracted 396 pledges for a total of $\mathrm{R} \$ 29,400$. The most distant donor in Project No. 1, which is located in Curitiba/PR, was in the city of Manaus (Amazonas State); this donor corresponds to a distance of $\sim 2825 \mathrm{~km}$. Country: Brazil

the influential observations and atypical cases (cases with standardized residuals $>2.5$ ) generated overestimations of the model. To this end, we tested the model after discarding cases where the residue was $>2.5$. The direction of the relationship between the variables and the significance remained the same. Sixth, we generated models by replacing the independent variables with their natural logarithms, and the results remained very close to the original model. Seventh, to see whether there was any significant influence of the projects on the relationship between the variables, we ran a model with nine dummy variables ( $n-1$ projects) as a control. The results still remained close to what was found in the original model.

Finally, because most of the donations occurred in the municipality in which the project was realized $(56.3 \%)$, there is a chance of having a selection bias. 
Table 3 Variables in the model

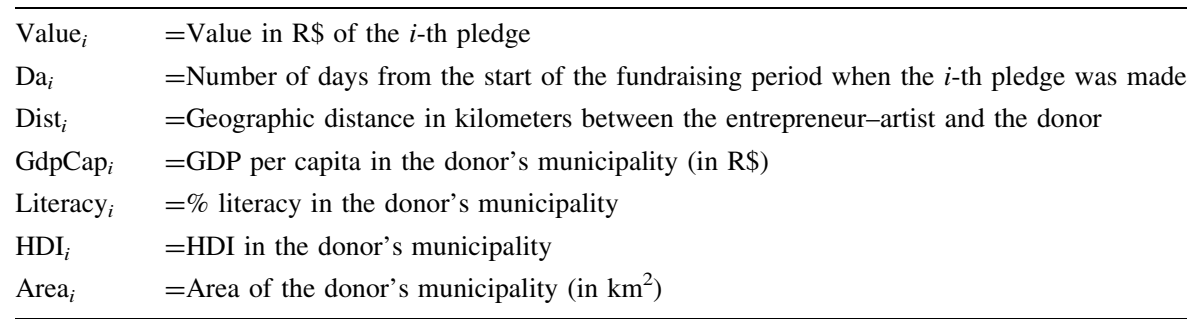

Therefore, we also used the Heckman's Two-Step Selection Method (Heckman 1979). In the first step, we specified as the selection variable the donor-entrepreneur distance with a probit model, where the value one was assigned to all of the donations that came from distant cities (802 cases) and zero was assigned to the donations originated from the same city project (1.033 cases). At this step, we included the control variables as predictors. In the second step, we included the inverse Mills ratio variable in the OLS model, which controls the potential effect of selection bias, together with the independent and control variables. It should also be noted that because we observed no data from unsuccessful projects, it was not possible to assess empirically whether there was a selection bias in the projects. However, we believe that the relationship between the distance and the exposure time with respect to the value of donations is similar to corresponding relationship of successful projects.

\section{Empirical results}

Table 4 shows the general characteristics of the set of projects included in this study. The full initial sample consisted of 1954 pledges to the ten projects. However, this figure included 119 anonymous pledges, which are allowed by the Catarse platform but do not provide information on the municipality from where the pledge was made. Thus, anonymous pledges were excluded, which left 1835 pledges that composed $94 \%$ of the original sample.

As indicated on Table 4, the entrepreneurs received on average more than 183 pledges during the fundraising period. This period lasted an average of 56 days, though one of the projects was submitted as a "Second Chance" and reached the target funds 101 days after the start of fundraising. Another project achieved its target funding level in just 35 days. The projects attracted on average $\mathrm{R} \$ 19,180.70$, with total funds between $\mathrm{R} \$ 10,000$ and $\mathrm{R} \$ 30,000$, which is in accordance with the inclusion criteria adopted for this study. The average pledge was $\mathrm{R} \$ 104.50$, and the pledges varied from $R \$ 10.00$ to $R \$ 5000.00$. The average distance was $0 \mathrm{~km}$, given that the majority of the sponsors (1033 of the total) were located in the same municipality as the project. The most distant sponsor was in Bonfim in Roraima (North of Brazil) for a project based in São Paulo (financial center of Brazil, in the 
Table 4 Descriptive statistics for the variables included in the research

\begin{tabular}{|c|c|c|c|c|c|}
\hline & Average & Median & Min. & Max. & $\begin{array}{l}\text { Standard } \\
\text { deviation }\end{array}$ \\
\hline \multicolumn{6}{|l|}{ Panel A: number of enterprises $(N=10)$} \\
\hline No. of pledges considered as received & 183.5 & 159 & 80 & 377 & 96.5 \\
\hline Total funds raised $(\mathrm{R} \$)$ & $19,180.7$ & 18,940 & 10,810 & 28,450 & 5538.8 \\
\hline No. of fundraising days & 56 & 58 & 35 & 101 & 18.9 \\
\hline \multicolumn{6}{|l|}{ Panel B: number of pledges $(N=1835)$} \\
\hline \multicolumn{6}{|l|}{ No. of Donors $=1575$} \\
\hline Value of investment (R\$) & 104.5 & 50 & 10 & 5.000 & 322.3 \\
\hline Geographic distance $(\mathrm{km})$ & 236.7 & 0 & 0 & 3297.7 & 456.4 \\
\hline $\begin{array}{l}\text { GDP per capita in the donor's } \\
\text { municipality (R\$) }\end{array}$ & $31,298.0$ & $30,400.5$ & 5441.7 & $115,319.9$ & $10,920.0$ \\
\hline Literacy in the donor's municipality (\%) & 89.9 & 90.3 & 73.1 & 92.0 & 1.9 \\
\hline HDI in the donor's municipality & 0.807 & 0.805 & 0.625 & 0.847 & 0.029 \\
\hline Area of the donor's municipality $\left(\mathrm{km}^{2}\right)$ & $1,100.8$ & 675 & 30.8 & $34,096.4$ & 1420.0 \\
\hline
\end{tabular}

This study considered 10 different music production projects that received 1835 pledges (from across Brazil)

Source: Catarse Website. Demographic indicators: IBGE (Brazilian Institute of Geography and Statistics) HDI human development index

Southeast), which represents a distance of $3297.7 \mathrm{~km}$. In accordance with the study conducted by Agrawal et al. (2011) on the Sellaband site, the propensity of sponsors to invest increased as the funds raised by the entrepreneur increased.

From Fig. 3, one can see that the distribution of pledges is very homogeneous during the typical project period (up to 60 days). However, a positive correlation between the project maturing and the value of the pledge made is evident; this correlation is observed mainly in the final fundraising phase (50-60 days), with the average pledge made growing by nearly $70 \%$ in comparison with the period of 10-20 days (the period with the second-largest average pledge). The pledges after 60 days occurred when the projects were in a "Second Chance" phase, that is, they were more mature and still had the potential to reach the fundraising target if they were given the opportunity to review some of the problems encountered and make any necessary corrections. In this period, a drastic increase in the average pledge made can be greater than $\mathrm{R} \$ 250.00$, which again suggests the importance of project maturity on the sponsors' decision with regard to the value to be invested. This behavior supports the results obtained by Agrawal et al. (2011). However, we used OLS models, not models of binary response (such as Agrawal et al. 2011).

\subsection{Geographic distribution of pledges}

In the present research, the ten sample projects are based in six cities: four in São Paulo (SP), two in Curitiba (Paraná State), one in Florianópolis (Santa Catarina State), one in Itapema (Santa Catarina State), one in Niterói (Rio de Janeiro State) 


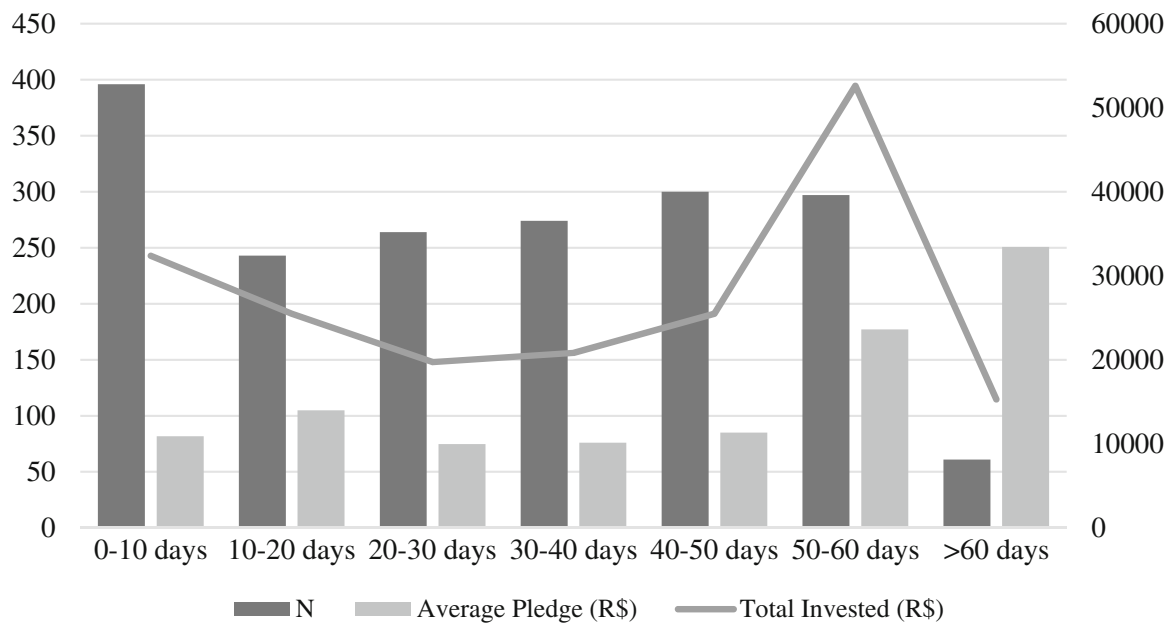

Fig. 3 Evolution of pledges over the fundraising period. Source: produced by the authors based on data collected on Catarse platform. Note this table shows how the average pledge values changed as the fundraising period progressed. Disregarding the project value of donations over 60 days, observe that as the hosted project matured, the value of the average pledge made via the platform appeared to increase

and one in Rio de Janeiro (Rio de Janeiro State). Pledges were made from 151 Brazilian municipalities and two foreign countries: Paris, France, and Neuchatel, Switzerland; these pledges were not included in the analysis. The average distance of the pledges was slightly over $236 \mathrm{~km}$.

As discussed previously, empirical studies suggest that entrepreneurial initiatives tend to be funded by local donors for a range of reasons, such as the following: The monitoring costs are lower, there is better access to information, and active participation in decisions is possible. However, in the study conducted by Agrawal et al. (2011), the majority of pledges made to the projects studied were distant: The average distance between the entrepreneurs and donors was 3000 miles (or about $4828 \mathrm{~km}$ ), and the donations originated from more than 80 different countries around the world. Figure 4 shows the geographic distribution of all of the pledges. The lines represent each sponsor-entrepreneur connection. Table 5 shows the geographic distribution of these pledges.

As seen in Fig. 4, the majority of the pledges originate in regions closer to the project site. Specifically, most pledges are located within a radius of $50 \mathrm{~km}$ from the entrepreneur's location, and notably, the majority are within a distance of $5 \mathrm{~km}$. Local investments are also on average greater than more distant ones, suggesting that the shorter the distance to the entrepreneur is, the greater the propensity to invest larger sums will be, which agrees with the negative coefficient found for the distance variable in the regression we performed (see Table 6). This pattern indicates a negative association with the pledge value. In addition, it is worth noting the similar average pledge in the ten projects from a distance of more than $2500 \mathrm{~km}$.

These data suggest that in Brazil, contrary to the evidence found in the European crowdfunding market (Agrawal et al. 2011), the financing of projects from artists at 


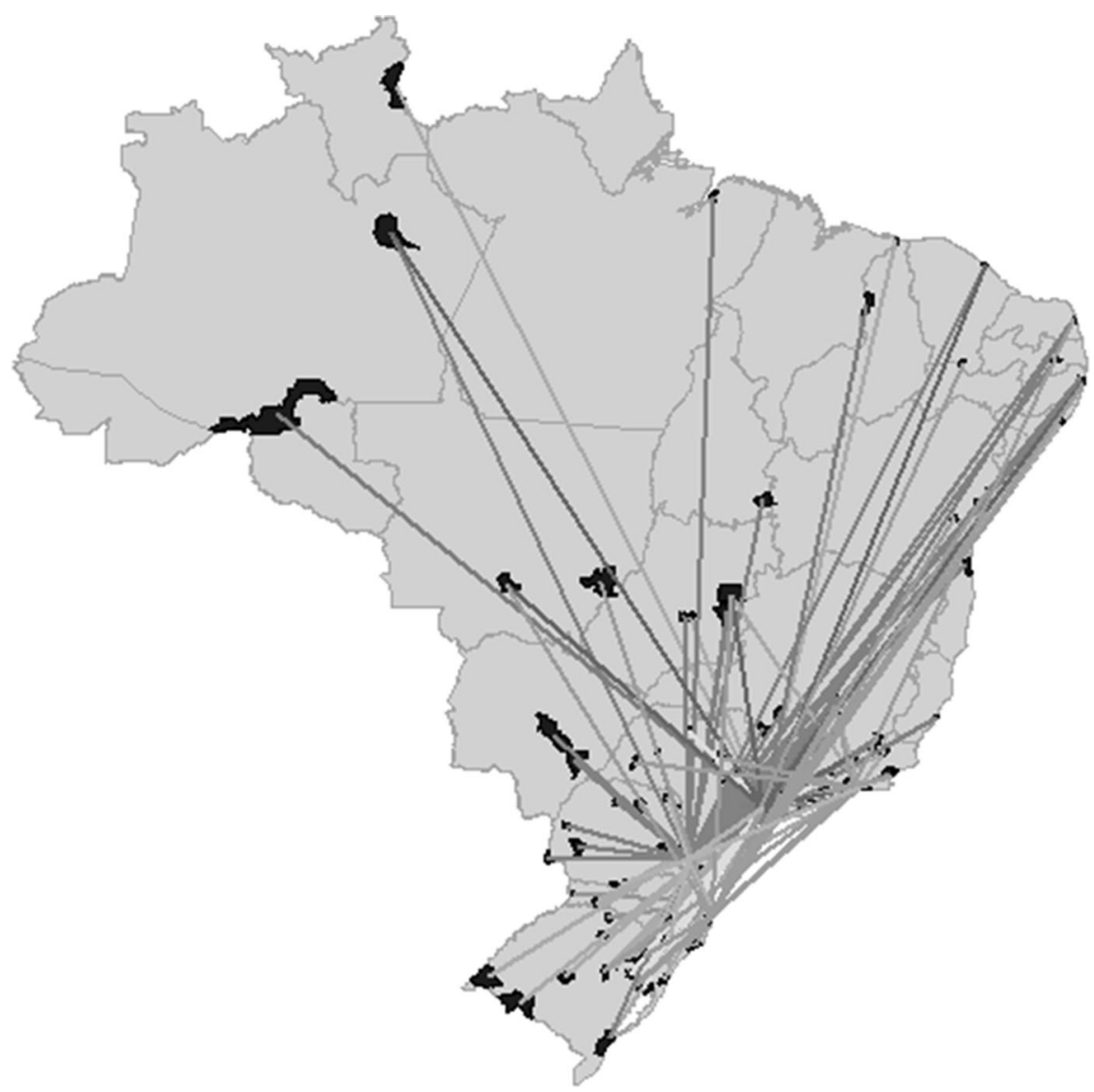

Fig. 4 Geographic distribution of all pledges (to projects hosted on the Catarse website). Source: produced by the authors from the data they collected using the tool ArcGIS ArcMap 10.0 (ESRI 2010). Note this figure shows the geographic spread of the 1835 pledges made to the 10 projects we examined, which are based in six different Brazilian cities: Curitiba (2), Florianópolis (1), Itapema (1), Niterói (1), Rio de Janeiro (1) and São Paulo (4)

the start of their careers predominantly revolves around their network of close contacts. The Catarse platform states on its website that at least $50 \%$ of the funds directed at projects come from the entrepreneur's own network of contacts.

As a consequence of this perception, the administrator of the platform has advised the managers of hosted projects that in parallel to posting on the platform, they should also aim to create a page for the project on a social network. The motivation is the expectation that the page followers could help increase the size of the managers' networks of close contacts, which a priori will be more disposed to financially support the project hosted on the platform. Still, it is fundamental that more than $22 \%$ of the total investment comes from distances $>50 \mathrm{~km}$, which represents a significant amount and suggests that the best-prepared and most 
Table 5 Frequency of investments by geographic distance

\begin{tabular}{lrccl}
\hline Distance $(\mathrm{km})$ & \multicolumn{1}{c}{$N$} & Average pledge $(\mathrm{R} \$)$ & Total invested $(\mathrm{R} \$)$ & \% of Total invested $(\%)$ \\
\hline $0-5$ & 1033 & 109.09 & 112,694 & 58.8 \\
$5-50$ & 218 & 166.95 & 36,395 & 19.0 \\
$50-500$ & 246 & 63.81 & 15,698 & 8.2 \\
$500-1500$ & 294 & 79.54 & 23,385 & 12.2 \\
$1500-2500$ & 34 & 60.88 & 2070 & 1.1 \\
$>2500$ & 10 & 156.50 & 1565 & 0.8 \\
Total & 1835 & 104.53 & 191,807 & 100 \\
\hline
\end{tabular}

Source: produced by the authors from the data they collected

attractive entrepreneurs on the platform might benefit from the availability of these more distant resources by expanding their funding possibilities. Thus, it is more likely that these entrepreneurs will achieve their fundraising targets.

The existence of associations between the value of a pledge, the fundraising days and the donor-entrepreneur distance was tested by hypotheses $\mathrm{H}_{1}$ and $\mathrm{H}_{2}$. To that end, tests were conducted with respect to model (1), whose parameters were estimated using the OLS and Heckman selection model and are given in Table 6. Model I produced the results obtained for the two variables of interest: Days from the start of the fundraising period and Donor-entrepreneur distance. It can be confirmed from Model I that $\mathrm{H}_{2}$ is supported, as Days from the start of the fundraising period gave a positive and significant parameter $\left(\hat{\beta}_{1} \cong 1.193 ; p\right.$ value $<0.01)$. Thus, there appears to be a significant association within the values pledged to the hosted projects. In addition to statistical significance, about the economic importance, as recommended by Miller and Rodgers (2008), note that the effect of another day on the value of each donation is small, around R \$ 1.2 (around US \$ 0.35 ), and this value seems to vary little, even considering the other controls adopted. However, as the average value of donations is approximately $\mathrm{R} \$ 50.00$, a period of 20 days of exposure could mean an increase of nearly $50 \%$ in the value, which is economically relevant.

These results support the arguments and findings of Agrawal et al. (2011), Zhang and Liu (2012) and Kuppuswamy and Bayus (2014) that greater accumulated time in the fundraising period for the hosted project implies a greater propensity for donors to pledge larger capital sums. This correlation is due to decreases in the uncertainty of the project.

The parameters estimated in Model I support hypothesis $\mathrm{H}_{1}$, as the parameter obtained for the donor-entrepreneur distance was negative and significant $\left(\hat{\beta}_{2} \cong-0.026 ; ; p\right.$ value $\left.<0.05\right)$. This result suggests that there are associations between the donor-entrepreneur distances and the values of pledges made to the hosted project, where the increase in one standard deviation in the distribution is related to a decrease of $\mathrm{R} \$ 11.90$ on the value of donations, which is also economically relevant. That is, more distant donors will be less disposed to invest larger sums in the project. This finding does not support the arguments that in the context of an emerging market, crowdfunding can be a sufficiently developed 


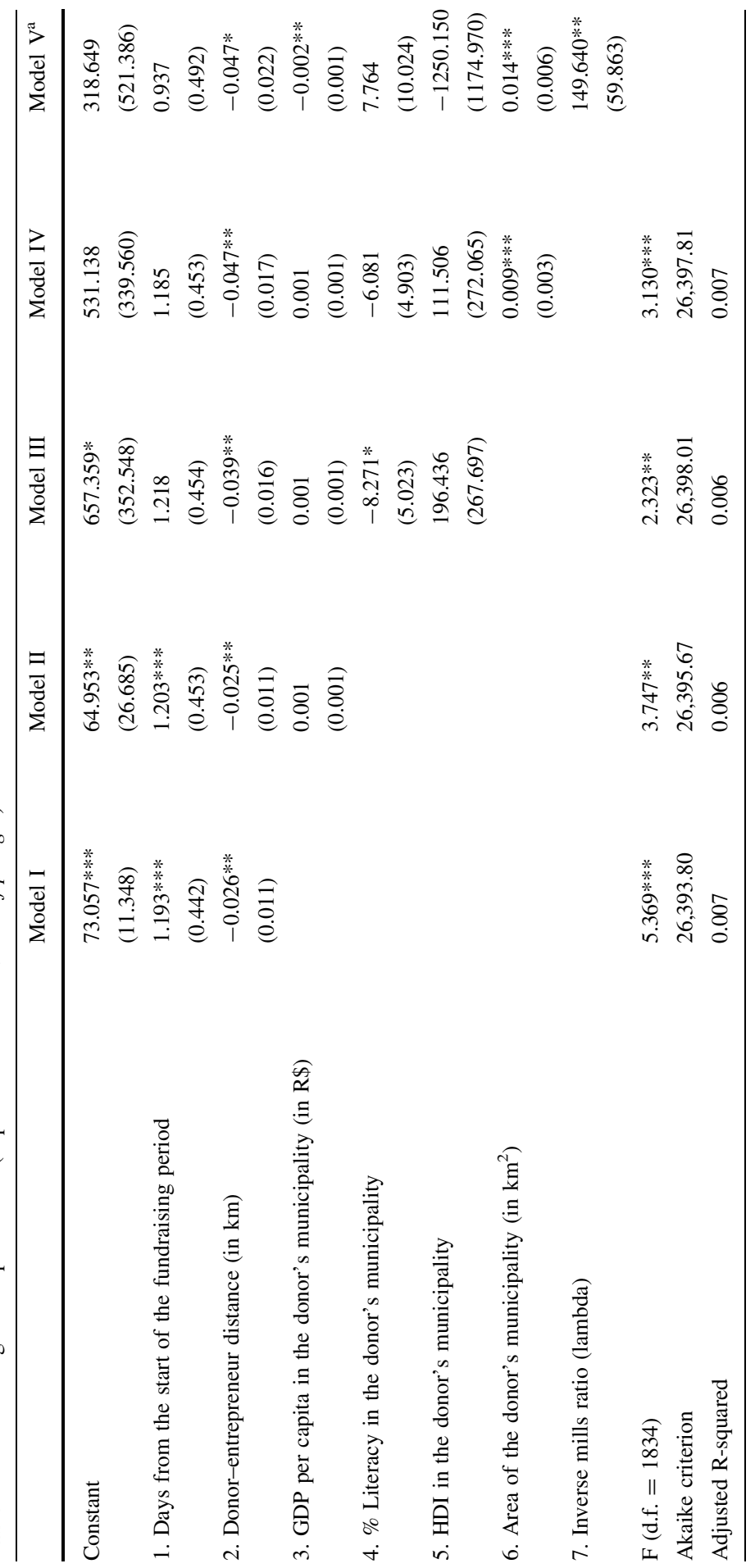




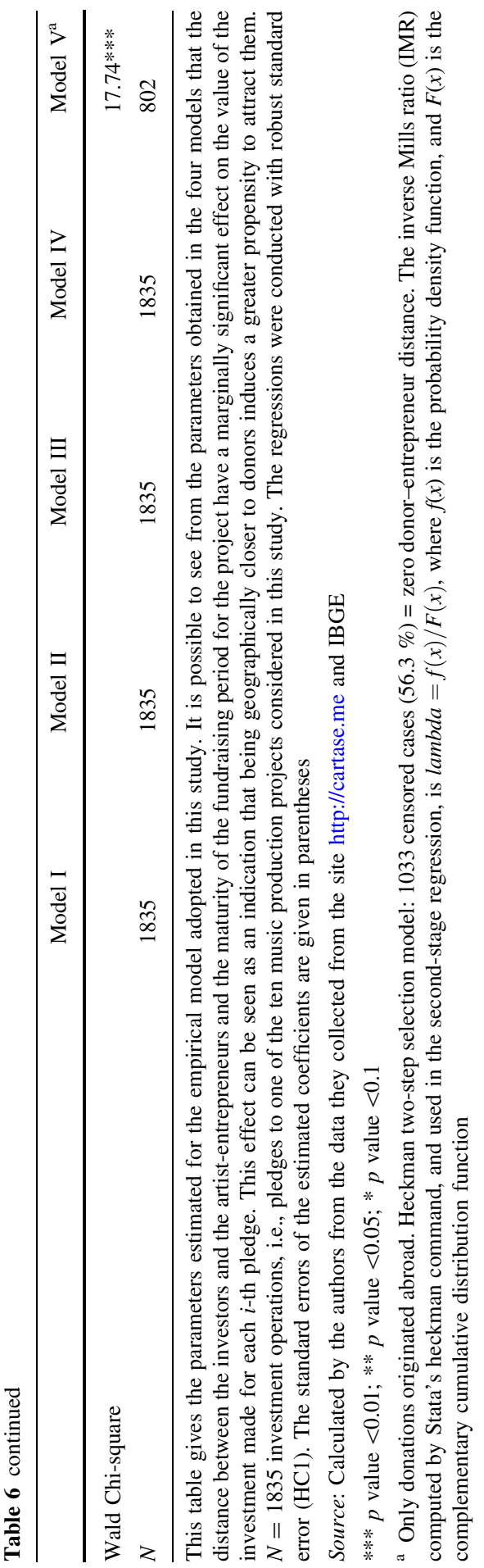


channel to supplant the information asymmetry imposed by the physical donorentrepreneur distance, as argued by Lee et al. (2008); at a minimum, no support for those arguments was found based on the data gathered from the main crowdfunding platform operating in Brazil. Conversely, the existence of concrete social relations networks between musicians and donors matter when deciding the amount of donation (Saxton and Wang 2014; Zheng et al. 2014; Colombo et al. 2015), as even these virtual relationships are, in many cases, supported in person (Wellman 1996).

After testing $\mathrm{H}_{1}$ and $\mathrm{H}_{2}$ separately in Model $\mathrm{I}$, the aim was to confirm the effect of the control variables related to the profile of the sponsor's municipality in Models II, III and IV. Model II shows that the wealth produced in the donor's municipality does not appear to influence the disposition of donors to pledge, i.e., the GDP per capita of the municipality is not a significant parameter $\left(\hat{\beta}_{1} \cong 0 ; p\right.$ value $\left.>0.1\right)$. However, Model III produced a counterintuitive result that suggests less awareness among public donors with a higher level of education. Indeed, larger numbers of literate inhabitants imply lower pledges $\left(\hat{\beta}_{4} \cong-827.082 ; p\right.$ value $\left.<0.1\right)$. However, this may be a spurious result, as it was not significant in the other models. We note that in Model III, the marginal effects of the variables of interest for the literate group were stronger than the corresponding effects included in Model I. In Model $\mathrm{IV}$, the results suggest that the largest municipalities in terms of area appear to generate larger sums of investment $\left(\hat{\beta}_{6} \cong 0.009 ; p\right.$ value $\left.<0.01\right)$.

In turn, the empirical model we tested (1) suggests that in all of the simulations, there are associations between the donor-entrepreneur distance and the value of each pledge received by the music production projects hosted on the Catarse crowdfunding platform, which is currently the largest in Brazil. In addition, significant indications of the effect of the fundraising time on the values of pledges were found when we considered the profile of the donor's municipalities. Finally, as most of the donations occurred within the municipality where the project was located, in Model V we simulated the relationship between the variables after excluding local donations. The results of the Heckman selection model, which served as a robustness check, corroborate the previous results, especially in the relationship between the variables the donor-entrepreneur distance and a donation's value: The greater the distance is, the lower the donated amount will be $\left(\hat{\beta}_{1} \cong 0.041\right.$ p value $<0.1$ ).

\section{Conclusions}

Crowdfunding is an evolving method for securing funds without the use of conventional equity markets. This financial innovation has enabled sources of funding for projects for a wide range of purposes, including cultural production projects, social projects and new technologies (Shiller 2013; Mollick 2014). Because it is supported by the internet, crowdfunding has the potential to make investment possible without the donors being close to the entrepreneurs. Even when dealing with small and medium investments in companies that are not listed on a stock exchange or in startups, it is only necessary for the entrepreneur to be able to 
provide relevant information to the donor, which reduces the information asymmetry, and therefore, the risks associated with the project. This fact increases the propensity of donors to pledge capital to the project.

However, evidence worldwide has suggested that such a project is dependent on the entrepreneur's network of personal contacts, including friends and family (Parker 2009; Agrawal et al. 2011; Sheng and Mendes-da-Silva 2014). In other words, even though crowdfunding has the potential to attract capital from donors who are more distant from the entrepreneur, the maturity level of the crowdfunding industry in particular situations and institutional environments may not provide the necessary conditions for this pattern to happen.

Because Brazil is a relevant emerging economy that seems to lack studies on how crowdfunding operates as a source of funding for small and medium projects, this article examined the existence of associations between the donor-entrepreneur distance and the propensity of donors to sponsor music production projects. In line with the notion that networks of close contacts might play a central role in funding, and simultaneously contradicting the idea that crowdfunding reduces the inhibiting effect of the geographic distance between donors and entrepreneurs, the results point to a significant, negative effect of distance on the amount of capital pledged to projects. These results corroborate hypothesis $\mathrm{H}_{1}$, which stated that there is a negative association between the donor-entrepreneur distances and the values of pledges to music production projects financed by crowdfunding.

These results support the arguments of Sorenson and Stuart (2001), Zook (2002), Stuart and Sorenson (2005), Mason (2007) and Martins (2015). In addition, they contradict the ideas proposed by Lee et al. (2008), for whom the internet performs a sufficiently expressive role to make the distance between the entrepreneur and donor insignificant in terms of the ability of entrepreneurs to receive pledges for their projects. The data showed that although the internet allows donations in a wider geographical range, this fact does not impact the values of donations. In addition, the results suggest that as the fundraising period progresses, the pledges to projects tend to increase in value; this pattern corroborates hypothesis $\mathrm{H}_{2}$, namely that there is a positive association between the time the project has spent on the platform and the value of the investment received by the entrepreneur. This result supports the arguments made by Zhang and Liu (2012) and by Kuppuswamy and Bayus (2014), for whom donors tend to have a greater propensity to invest in projects that they find hosted for a longer period of time on a crowdfunding platform.

The design of this research imposed limits on the work, which may restrict any generalizations that could be made from the results and point to a noteworthy set of issues: (1) the work only considered music projects, (2) the study was restricted to Brazil, (3) the time when the data were collected could have coincided with specific behavior for the variables studied, and (4) there were no individual-level data for donors. The issues investigated in this study add to the contemporary agenda for research into crowdfunding given by Lehner (2013), which appears to provide a promising field of business research. In addition, the results of this study suggest that crowdfunding requires new approaches that could help with the issues of attracting external capital, flexibility and financing costs, and asymmetric information on the part of donors. Accordingly, we encourage effort to be put into 
researching topics related to the development of the crowdfunding industry, e.g., (1) business and corporate governance models, (2) relationships with donors, (3) networks and the role performed by crowdfunding platforms, (4) discussions of the legitimacy of crowdfunding, (5) financial metrics, (6) legal and regulatory barriers and (7) recognition of opportunities.

Acknowledgments The authors would like to thank the owner of the Catarse website, which granted access to the data that enabled this research. The authors must also thank the Fundação Getulio Vargas Business School at São Paulo (FGV/SP) and the Brazilian Institute of Financial Innovation (IBRIF) for their financial support. Finally, we would like to thank Dr. Andrea Maria Accioly Fonseca Minardi for her valuable comments at the ANPAD annual meeting 2014 in Rio de Janeiro, Brazil, two anonymous reviewers, and especially editor Sam Cameron for dedication to the development of the paper. The findings and conclusions expressed are the sole responsibility of the authors and do not necessarily represent the position of the institutions to which they are attached.

Open Access This article is distributed under the terms of the Creative Commons Attribution 4.0 International License (http://creativecommons.org/licenses/by/4.0/), which permits unrestricted use, distribution, and reproduction in any medium, provided you give appropriate credit to the original author(s) and the source, provide a link to the Creative Commons license, and indicate if changes were made.

\section{References}

Agrawal, A. K., Catalini, C., \& Goldfarb, A. (2011). The geography of crowdfunding [Working Paper $\mathrm{N}^{\circ}$ 16820]. National bureau of economic research. Cambridge, MA. doi: 10.3386/w16820.

Agrawal, A. K., Catalini, C., \& Goldfarb, A. (2014). Some simple economics of crowdfunding. Innovation Policy and the Economy, 14(1), 63-97. doi:10.3386/w19133.

Ahlers, G. K. C., Cumming, D., Guenther, C., \& Schweizer, D. (2012). Signaling in equity crowdfunding. Social Science Research Network, doi:10.2139/ssrn.2161587.

Ariely, D., Bracha, A., \& Meier, S. (2009). Doing good or doing well? Image motivation and monetary incentives in behaving prosocially. American Economic Review, 99(1), 544-555. doi:10.1257/aer. 99.1.544.

Belleflamme, P., Lambert, T., \& Schwienbacher, A. (2014). Crowdfunding: tapping the right crowd. Journal of Business Venturing, 29(5), 585-609. doi:10.1016/j.jbusvent.2013.07.003.

Berger, A. N., \& Udell, G. F. (1998). The economics of small business finance: the roles of private equity and debt markets in the financial growth cycle. Journal of Banking and Finance, 22(6-8), 613-673. doi:10.1016/S0378-4266(98)00038-7.

Brabham, D. C. (2008). Crowdsourcing as a model for problem solving: an introduction and cases. Convergence: The International Journal of Research into New Media Technologies, 14(1), 75-90. doi: $10.1177 / 1354856507084420$.

Braet, O., Spek, S., \& Pauwels, C. (2013). Crowdfunding the movies: A business analysis of crowdfinanced moviemaking in small geographical markets. Journal of Media Business Studies, 10(1), 1-23. doi:10.1080/16522354.2013.11073557.

Bruton, G., Khavul, S., Siegel, D., \& Wright, M. (2015). New financial alternatives in seeding entrepreneurship: Microfinance, crowdfunding, and peer-to-peer innovations. Entrepreneurship Theory and Practice, 39(1), 9-26. doi:10.1111/etap.12143.

Burt, R. S. (2005). Brokerage and closure: An introduction to social capital. Oxford: Oxford University Press.

Burtch, G., Ghose, A., \& Wattal, S. (2013). An empirical examination of the antecedents and consequences of contribution patterns in crowd-funded markets. Information Systems Research, 24(3), 499-519. doi:10.2139/ssrn.1928168.

Cameron, S. (2015). Music in the marketplace: A social economics approach (Routledge advances in social economics). New York: Routledge. ISBN 978-0415723275. 
Cassiolato, J. E., Matos, M., \& Lastres, H. (2008). The sounds of Brazil: The popular music and the music industry. In D. Barrowclough \& Z. Kozul-Wright (Eds.), Creative industries and developing countries: Voice, choice and economic growth (pp. 146-173). Oxon: Routledge.

Coleman, J. S. (1990). Foundations of social theory. Cambridge: Harvard University Press.

Colombo, M. G., Franzoni, C., \& Rossi-Lamastra, C. (2015). Internal social capital and the attraction of early contributions in crowdfunding. Entrepreneurship Theory and Practice, 39(1), 75-100. doi:10. 1111/etap.12118.

Cosh, A., Cumming, D., \& Hughes, A. (2009). Outside entrepreneurial capital. Economic Journal, 119(540), 1494-1533. doi:10.1111/j.1468-0297.2009.02270.x.

Drummond, M., \& O'Brienm, B. (1993). Clinical importance, statistical significance and the assessment of economic and quality-of-life outcomes. Health Economics, 2(3), 205-212. doi:10.1002/hec. 4730020303.

Ebner, W., Leimeister, J. M., \& Krcmar, H. (2009). Community engineering for innovations: the ideas competition as a method to nurture a virtual community for innovations. R\&D Management, 39(4), 342-356. doi:10.1111/j.1467-9310.2009.00564.x.

ESRI. (2010). ArcGIS ArcMap, version 10.0: desktop GIS software. Redlands, CA: ESRI Inc.

Ferrary, M., \& Granovetter, M. (2009). The role of venture capital firms in Silicon Valley's complex innovation network. Economy and Society, 38(2), 326-359. doi:10.1080/03085140902786827.

Goodchild, M. (2010). Twenty years of progress: GIScience in 2010. Journal of Spatial Information Science, 1, 3-20. doi:10.5311/JOSIS.2010.1.2.

Heckman, J. (1979). Sample selection as a specification error. Econometrica, 47(1), 153-161. doi:10. $2307 / 1912352$.

Heminway, J., \& Hoffman, S. (2011). Proceed at your peril: Crowdfunding and the securities act of 1933. Tennessee Law Review, 78(4), 879-972.

IFPI. (2010). Recording industry in numbers 2010. London: IFPI.

IFPI. (2014). IFPI digital music report 2014. London: IFPI.

Kim, K., \& Hann, I.H. (2014). Crowdfunding and the democratization of access to capital: a geographical analysis. Robert H. Smith School Research Paper. College Park, MD. doi:10.2139/ssrn.2334590.

Kuppuswamy, V., \& Bayus, B. L. (2014). Crowdfunding creative ideas: The dynamics of project backers in Kickstarter [working paper $\mathrm{N}^{\circ}$ 2013-15]. UNC Kenan-Flagler Research Paper, Chapel Hill, NC. doi: $10.2139 /$ ssrn.2234765.

Kuti, M., \& Madarász, G. (2014). Crowdfunding. Public Finance Quarterly, 59(3), 355-366.

Lee, S. H., DeWester, D., \& Park, S. R. (2008). Web 2.0 and opportunities for small businesses. Service Business, 2(4), 335-345. doi:10.1007/s11628-008-0043-5.

Lehner, O. M. (2013). Crowdfunding social ventures: A model and research agenda. Venture Capital: An International Journal of Entrepreneurial Finance, 15(4), 289-311. doi:10.1080/13691066.2013. 782624.

Lucas, M. E. (2000). Gaucho musical regionalism. British Journal of Ethnomusicology, 9(1), 41-60. doi:10.1080/09681220008567291.

Macht, S. A. (2014). Reaping value-added benefits from crowdfunders: What can we learn from relationship marketing? Strategic Change, 23(7-8), 439-460. doi:10.1002/jsc.1988.

Martins, L. V. B. (2015). Syndicated investing in private equity and venture capital industry: Comparing BRICS. Journal of Financial Innovation, 1(1), 18-39. doi:10.15194/jofi_2015.v1.i1.8.

Mason, C. (2007). Venture capital: A geographical perspective. In H. Landström (Ed.), Handbook of research on venture capital (pp. 86-112). Cheltenham: Edward Elgar.

Massolution. (2013). 2013CF the crowdfunding industry report. Los Angeles: Crowdsourcing.

Matzat, U. (2004). The social embeddedness of academic online groups in offline networks as a norm generating structure: An empirical test of the Coleman model on norm emergence. Computational and Mathematical Organization Theory, 10(3), 205-226. doi:10.1023/B:CMOT.0000045369.98848. 71.

McPhearson, M., Smith-Lovin, L., \& Cook, J. M. (2001). Birds of a feather: Homophily in social networks. Annual Review of Sociology, 27, 415-444. doi:10.1146/annurev.soc.27.1.415.

Mendes-da-Silva, W., Brito, T. F. S., Famá, R., \& Liljegren, J. (2008). Effects of friendship in transactions in an emerging market: Empirical evidence from Brazil. The Icfai University Journal of Behavioral Finance, 5(2), 25-46.

Miller, J. E., \& Rodgers, M. Y. (2008). Economic importance and statistical significance: Guidelines for communicating empirical research. Feminist Economics, 14(2), 117-149. doi:10.1080/ 13545700701881096. 
Mollick, E. R. (2014). The dynamics of crowdfunding: An exploratory study. Journal of Business Venturing, 29(1), 1-16. doi:10.1016/j.jbusvent.2013.06.005.

Nahapiet, J., \& Ghoshal, S. (1998). Social capital, intellectual capital, and the organizational advantage. Academy of Management Review, 23(2), 242-266. doi:10.2307/259373.

Nichols, A. (2003). Vincenty: Stata module to calculate distances on the Earth's surface. St. Louis: Ideas. Retrieved January 10, 2014 from https://ideas.repec.org/c/boc/bocode/s456815.html.

Parker, S. C. (2009). The economics of entrepreneurship. Cambridge: Cambridge University Press.

Preacher, K. J., \& Hayes, A. F. (2008). Asymptotic and resampling strategies for assessing and comparing indirect effects in multiple mediator models. Behavior Research Methods, 40(3), 879-891. doi:10. 3758/BRM.40.3.879.

Qiu, C. (2013). Issues in crowdfunding: Theoretical and empirical investigation on Kickstarter. Social Science Research Network, doi:10.2139/ssrn.2345872.

Redaelli, E. (2012). Cultural planning in the United States: Toward authentic participation using GIS. Urban Affairs Review, 48(5), 642-669. doi:10.1177/1078087412441158.

Royal, C., \& Windsor, G. S. S. (2014). Microfinance, crowdfunding, and sustainability: A case study of telecenters in a South Asian developing country. Strategic Change, 23(7-8), 425-438. doi:10.1002/ jsc. 1987.

Saxton, G. D., \& Wang, L. (2014). The social network effect: The determinants of giving through social media. Nonprofit and Voluntary Sector Quarterly, 43(5), 850-868. doi:10.1177/0899764013485159.

Schwartz, A. A. (2013). Rural crowdfunding [working paper $\mathrm{N}^{\circ} 13-18$ ]. Legal Studies Research Paper Series, Boulder, CO. Retrieved January 18, 2014 from http://ssrn.com/abstract=2356643.

Schwienbacher, A., \& Larralde, B. (2012). Crowdfunding of entrepreneurial ventures. In D. Cumming (Ed.), The oxford handbook of entrepreneurial finance (pp. 369-391). Oxford: Oxford University Press.

Sheng, H. H., \& Mendes-da-Silva, W. (2014). The big family: Informal financing of small and mediumsized business by Guanxi. Thunderbird International Business Review, 56(2), 157-171. doi:10.1002/ tie. 21609 .

Shiller, R. (2013). Capitalism and financial innovation. Financial Analysts Journal, 69(1), 21-25. doi:10. 2469/faj.v69.n1.4.

Sorenson, O., \& Stuart, T. E. (2001). Syndication networks and the spatial distribution of venture capital investments. American Journal of Sociology, 106(6), 1546-1588. doi:10.1086/321301.

Stemler, A. R. (2013). The JOBS act and crowdfunding: Harnessing the power-and money-of the masses. Business Horizons, 56(3), 271-275. doi:10.1016/j.bushor.2013.01.007.

Stuart, T., \& Sorenson, O. (2005). Social networks and entrepreneurship. In S. Alvarez, R. Agarwal, \& O. Sorenson (Eds.), Handbook of entrepreneurship research (pp. 233-252). New York: Springer.

Sui, D. Z., Elwood, S., \& Goodchild, M. (2013). Crowdsourcing geographic knowledge. New York: Springer.

Wellman, B. (1996). Are personal communities local? A dumptarian reconsideration. Social Networks, 18(4), 347-354. doi:10.1016/0378-8733(95)00282-0.

World Bank. (2013). Crowdfunding's potential for the developing world. Washington, DC: World Bank.

Zhang, J., \& Liu, P. (2012). Rational herding in microloan markets. Management Science, 58(5), 892-912. doi:10.1287/mnsc.1110.1459.

Zheng, H., Li, D., Wu, J., \& Xu, Y. (2014). The role of multidimensional social capital in crowdfunding: A comparative study in China and US. Information and Management, 51(4), 488-496. doi:10.1016/ j.im.2014.03.003.

Zook, M. A. (2002). Grounded capital: Venture financing and the geography of the internet industry, 1994-2000. Journal of Economic Geography, 2(2), 151-177. doi:10.1093/jeg/2.2.151. 